\title{
MEDGYESSYS DIÁKOK MÜONKAMRÁT ÉPÍTETTEK A DEBRECENI EGYETEMEN
}

\section{Szerző:}

Borbélyné Bacsó Viktória (PhD) Medgyessy Ferenc Gimnázium és Művészeti Szakgimnázium

Szerző e-mail címe: bacsoviktoria@gmail.com

\section{Lektorok:}

Mező Katalin (PhD)

Debreceni Egyetem

Mező Ferenc (PhD)

Eszterházy Károly Egyetem

...és további két anonim lektor

\begin{abstract}
Absztrakt
A Földre érkező kozmikus sugarak fontos alkotóelemei a müonok, amelyeket (például) a CERN tudósai kutatnak. Projektünk bemutatja, hogy középiskolások is képesek müondetektorot (úgynevezett müonkamrát) építeni megfelelő pedagógiai támogatás segítségével. A projekt a debreceni Medgyessy Ferenc Középiskola és Művészeti Gimnázium és a Debreceni Egyetem Fizikai Intézete közreműködésével valósult meg.
\end{abstract}

Kulcsszavak: müon, fizika, középiskolás diákok, tehetséggondozás

Diszciplina: pedagógia, fizika

\section{Abstract \\ STUDENTS OF MEDGYESSY GYMNASIUM \\ BUILT A MUON CHAMBER AT THE UNIVERSITY OF DEBRECEN}

Important components of cosmic rays arriving on Earth are muons, which are researched by (for example) the scientists of CERN. Our project shows that also secondary school students can build muon-detector (so-called: muon chamber) with the help of adequate pedagogical support. This project was realized in cooperation of the Medgyessy Ferenc High School and Art High School in Debrecen and the Institute of Physics of the University of Debrecen.

Keywords: muon, physics, secondary school students, talent development

Discipline: pedagogy, physics

Borbélyné Bacsó Viktória (2020): Medgyessys diákok müonkamrát építettek a Debreceni Egyetemen. OxIPO - interdiszciplináris tudományos folyóirat, 2020/2, 87-90. doi: 10.35405/OXIPO.2020.2.87 
A Földre érkező kozmikus sugarak fontos összetevői a müonok, amelyek a Földet is elérő, nagy áthatoló képességű töltött részecskék. A nagyenergiás fizika mellett a müonok alkalmazhatók környezettanulmányokra, mint például a hó mélységének mérésére a hegyeken, a piramisok, barlangok rejtett kamráinak keresésére, a vulkánok belső szerkezetének vizsgálatára. Ilyen részecskefizikai vizsgálatok elvégzésére már nem csak a CERN tudósai képesek. Megfelelő szakmai irányítás mellett középiskolás diákok is összerakhatnak olyan részecskedetektort, amely alkalmas a kozmikus müonok detektálására.

\section{A Medgyessy Ferenc Gimnázium és Müvészeti} Szakgimnáziumban kiemelt feladatként tekintünk a tehetséggondozásra. Tanulóinkat számos irányból érik fejlesztő impulzusok, ezért nyitottak a kreatív kihívásokra. A Debreceni Egyetem Fizikai Intézetével történő együttműködés keretében a reál érdeklődésű tanulóinkat is igyekszünk minél több irányból fejleszteni. Több éve veszünk részt olyan kutatásokban, amelyek megalapozhatják diákjaink műszaki, természettudományos vagy informatikai irányú egyetemi továbbtanulását.

Programunk célja egy müonkamra összerakása volt, amely képes a kozmikus részecskék kimutatására, pályájuk feltérképezésére, fizikai mérésre. Az angol nyelvű szakirodalmom böngészése, fordítása nem okozott gondot, nyelvi tagozatos diákok számára, tudásukat már csak a témával kapcsolatos szakkifeje- zésekkel kellett bővíteniük. A megfelelő elméleti megalapozás után következett a kamra alkotóelemekből való összerakása, elsőként a nyáklap megtisztítása. Ezután mindent saját kezúleg, saját hibáikból tanulva „legóztak” a megfelelő helyre. Minden réteget külön-külön hoztunk létre: a nyáklapra ráültettük a kamra oldalait, majd kétféle vastagságú huzalt tekercseltünk és forrasztottunk a lapra. Ezek érzékelik a részecskék becsapódását kísérő „lavina” keletkezését. Speciális csévélő eszköz híján a legtöbb fejtörést a fémszálak megfelelő feszességének beállítása, a súlyozás optimális módjának kiválasztása volt. Végezetül elektronikával szereltük fel a berendezést, majd a felső lap rögzítése után a kamrákat argonszéndioxid gáz keverékével tölöttük fel. A tevékenység nagy fokú precizitást, odafigyelést igényelt.

Az alapjanál elkezdett munka során a funkció és mûködés a tanulók számára is egyértel-művé vált, gyakorlatorientáltan fejlesztve a diákok műszaki kompetenciáit. A fô szempontok a költséghatékonyság, a hordozhatóság és a szakköri keretek között történő megvalósíthatóság voltak (1. kép)

\section{1. kép: Kezdeti lépések. (Forrás: Szerzô)}
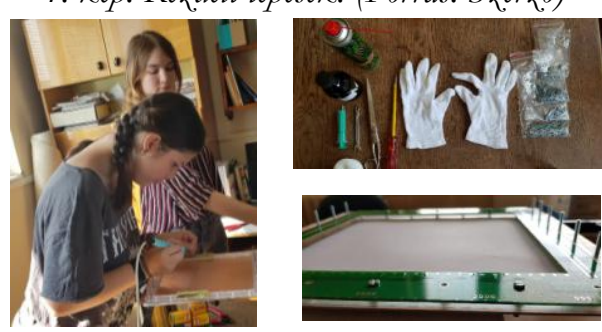
A kamra összállítása lépésenként történt, az egyes rétegeket csavarokkal és ragasztással váltak egy egésszé. Kritukus lépés a szálak forrasztása, mivel ezt súlyokkal történt, ekkorra stabilan kellett állni a rétegeknek, ha utólag elmozdul, a szál nem lesz elég feszes a detektáláshoz. (2. kép).

\section{2. kép: Kifeszitett szálak (forrás: Szerző́)}

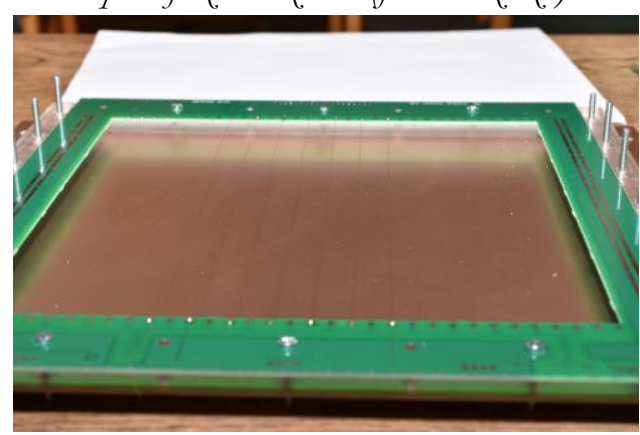

Nagy izgalmat kiváltó eseményként éltük meg munkánk tesztelésénél a müonok pályájának megjelenítését. Ledek felvillanása jelezte a becsapódó részecskéket, amikor a kamrára szerelt elektronika életre kelt (3. kép).

\section{3. kép: A kamra életre kelt (forrás: Szerző)}

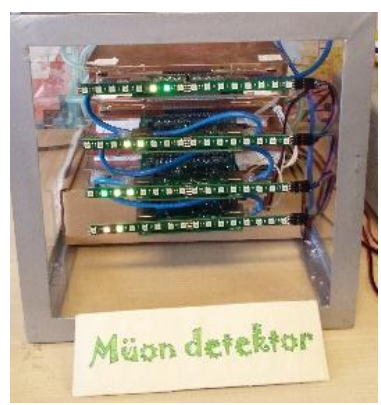

Tevékenységünkhöz hozzá tartozott az elektronika működtetéséhez szükséges kiolvasó program tanulmányozása is, amelynek megismerése hozzájárult a tanulók informatikai és matematikai kompetenciájának fejlesztéséhez. Dr. Újvári Balázs egyetemi adjunktus és $\mathrm{PhD}$ hallgatói, illetve Korcsmáros Berta tanszéki mérnökök irányítása mellett, a tanulók a müondetektor adatkiolvasó rendszeréhez olyan feldolgozó algoritmusokat is készítettek, amivel elkülöníthetőek a müonok által keltett felvillanások az úgynevezett „zajtól”.

A kamra múködése során nyert adatokat virtuális térbe átültetve, diákjaink segédkezhettek egy játékprogram létrehozásában is, amellyel müonokra „vadászhattunk a"VR-térben. (4. kép).

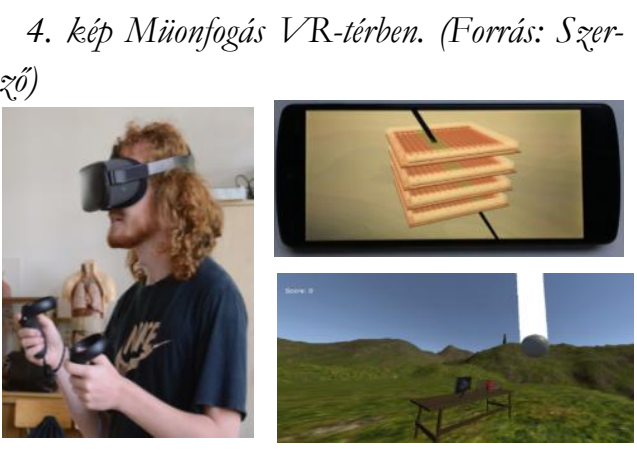

A kamra építése egy komplex munka volt, amelynek része a szimuláció, a mérnöki tervezés, a technikusi összeszerelés, a programozói szemléletű fejlesztés és az eredmény fizikusi nézőpontból való elem- 
zése. Az igazi eredmény ezen képességek együttes gyakorlása során jött létre, mert a diákok átélhették egy sokrétű munka folyamatát, s eközben megtudták, hogy mely mozzanat múvelése okozza számukra a legnagyobb sikert, elégedettséget, és ez nagymértékben befolyásolta pályaválasztásukat és a fizika tantárgy iránti elkötelezettségüket. 